International Journal of Engineering \&Technology, $8(4)(2019) 444-453$
International Journal of Engineering \& Technology
SPC
Website: www.sciencepubco.com/index.php/IJET
Research paper

\title{
Recursive Model: Cognitive Learning Behavior in Online Consumers
}

\author{
IrwanChristanto Edy ${ }^{1 *}$, Riyanto ${ }^{2}$ \\ ${ }^{1}$ STIE “Adi UnggulBhirawa”, Surakarta, Indonesia \\ ${ }^{2}$ Universitas PGRI, Semarang, Indonesia \\ *Corresponding author_E-mail:irwan_aub@yahoo.co.id
}

\begin{abstract}
Online purchasing decisions are online consumer behavior and are an interesting phenomenon in research. This study aims to prove the concept that online consumer purchasing decisions are influenced by cognitive learning behavior. The main theory underlying this research is consumer behavior and learning. Learning theory is used to analyze consumer learning behavior online with a mix of (crossing) learning theories of behavior and cognitive learning theory. Combination (crossing) between behavioral learning theory, cognitive is called cognitive learning behavior (cognitive learning behavior). This research is a survey. The data used are primary data, with the research instrument in the form of a questionnaire. The subjects of this study are individuals namely online consumers. Online consumers in this study are millennial generation who have made online purchases on one of the e-commerce sites in Indonesia (Matahari.mall, bukalapak, tokopedia, shopee, Zilingo) with this type of product is fashion. In this study 200 respondents were selected. The study consisted of organic stimulation of marketing on the website, online purchasing decisions, cognitive learning, experience preferences. Convenience sampling sampling technique is a sampling method where sampling is based on the availability of elements and the ease of obtaining them. Collecting data with online questionnaires and distributing questionnaires through whatsapp to respondents who are easily contacted by researchers. Data analysis methods with 1) test data quality instruments (validity and reliability), 2) Analysis of Descriptive Statistics and 3) Model Analysis with SEM. The results showed that 1) Organic stimulation of marketing on the website had a positive and significant effect on cognitive learning, 2)experience preference had a positive and significant effect on cognitive learning, 3)cognitive learning had a positive and not significant effect on online purchasing decisions, 4) experience preference had a positive and not significant effect on online purchasing decisions, 5) Organic stimulation of marketing on the website had a positive and significant effect on online purchasing decisions.
\end{abstract}

Keywords: Organic Stimulation of Marketing on the Website; Experience Preference; Cognitive Learning; Online Consumer Purchasing Decisions.

\section{Introduction}

Consumer behavior is an interesting empirical concern (Darley et al., 2010; Limbu et al., 2012;) and becomes the estuary of various management theories (Kotler, 2012). Purchasing decisions are consumer behavior that is influenced by various factors (Kotler and Keller, 2009; Park and Kim, 2003). Technology is one of the factors that influence consumer behavior (Akbar, 2014). Marketing involving the internet is often known as online marketing (Pomerleanu et al., 2013; Tiago and Siimo, 2014; Coviello et al., 2001; Cho et al., 2006; Santoso, 2009). Online marketing is an online purchase through mobile, social media (Facebook, Twitter, Instagram) (Pietro and Pantano, 2012; Edy and Tiningrum, 2015; Ekasari, 2014; Nurgayatri, 2016), and website retailers (Mataharimall.com, Bukalapak.com , Tokopedia, Shopee, Shopee, Lazada and so on) (Cugelman, 2010; Furkonudin et al, 2016; Lin et al., 2017; Rosen and Purinton, 2004). Some reasons consumers like online purchases because: 1) consider cheaper (38\%), 2) happy to be seen 24 hours (35\%), 3) happy to have free shipping (31\%), 4) feel saving time (30.8) (APJII, 2017). Real data have not shown the role of cognitive learning as the reason for consumers' online purchases (reality gaps). Previous research studies prove that various factors influence online marketing such as 1) consumer psychology (Bagozzi and Dholakia, 2002; Zhonghua, 2002; Koufaris et al., 2002; Afandy et al., 2014; Caraka and Rachmawati, 2015), 2) cognitive consumers (El-Gohari, 2010; Kim and Song, 2010), 3) multi-channel internet (Badrinarayanan et al., 2012; Ardianto, 2016), 4) experience (Im et al., 2010; Shultz and Peltier, 2013; Yoon, 2010), 5) consumer characteristics (Debre and MilovanCiuta, 2015; Kusumowidagdo, 2012; Rohm and Swaminathan, 2004), 6) consumer perceptions (Affecting et al., 2011; Milan et al., 2015; Cho et al., 2002; Vachani and Bhayani, 2012), 7) website and its quality (Abideen and Saleem, 2012; Salehi, 2011; Geetha and K. Rangarajan, 2016; Al-Jabari et al., 2012; Abarbanel et al ., 2015), 8) information, intention, motivation and ethics (Liu, Wan and Yan, 2010; Anggraeni et al., 2016; Fihartini, 2017; Jalalkamali and Nikbin, 2010; Joines et al., 2003), 9) characteristics of marketing mix (Azzadina, 2012; Ku sumah, 2015).

Cummins et al., (2014) reviewed 942 articles since 2012 on online consumer behavior found that cognitive issues are the most researched research topics which include information processing, learning, memory and motivation issues (Childers et al., 2001). 
Table 1:Mapping the Issue of Online Consumer Behavior and Social Media

\begin{tabular}{|c|c|c|c|c|c|c|c|c|}
\hline Category & \multicolumn{2}{|c|}{$\begin{array}{c}\text { Incubation } \\
\text { era 1993-2004 } \\
\text { Era }\end{array}$} & \multicolumn{2}{|c|}{$\begin{array}{l}\text { Exploration } \\
\text { era } 2005-2008\end{array}$} & \multicolumn{2}{|c|}{$\begin{array}{c}\text { Explosion era } \\
2009-2012\end{array}$} & \multicolumn{2}{|c|}{$\begin{array}{c}\text { Total } \\
1993-2012\end{array}$} \\
\hline Cognitive issues & 65 & 30.0 & 86 & 29.6 & 103 & 23.7 & 254 & 27.0 \\
\hline User-generated content & 6 & 2.8 & 41 & 14.1 & 95 & 21.9 & 142 & 15.1 \\
\hline $\begin{array}{l}\text { Internet segmentation and } \\
\text { demographics }\end{array}$ & 27 & 12.4 & 44 & 15.1 & 51 & 11.8 & 122 & 12.9 \\
\hline Online usage & 37 & 17.1 & 32 & 11.0 & 32 & 7.4 & 101 & 10.7 \\
\hline Cross-cultural & 28 & 12.9 & 29 & 10.0 & 37 & 8.5 & 94 & 10.0 \\
\hline $\begin{array}{l}\text { Online communities and } \\
\text { networks }\end{array}$ & 17 & 7.8 & 21 & 7.2 & 42 & 9.7 & 80 & 8.5 \\
\hline $\begin{array}{l}\text { Strategic use and } \\
\text { outcomes }\end{array}$ & 15 & 6.9 & 27 & 9.3 & 35 & 8.1 & 77 & 8.2 \\
\hline Consumer Internet search & 22 & 10.1 & 11 & 3.8 & 39 & 9.0 & 72 & 7.6 \\
\hline Total & 217 & 100.0 & 291 & 100.0 & 434 & 100.0 & 942 & 100 \\
\hline
\end{tabular}

Source : Cummins et al (2014).

The study of cognitive is rooted in the psychological model of learning and information which still has wide and interesting space for online consumer behavior research because there are strategic and operational considerations (Cummins et.al., 2014). Research on psychological construction in the domain of e-commerce only scratches the surface (Kim and Lennon, 2013), has not touched on the substantial. Previous research has not explored in depth the role of cognitive learning behavior in online consumers (Rosenkran, 2010; Kang et al., 2006; Luna et al., 2002; Sundar and Kalynaraman, 2004).

The limitations of previous research, direct this study to explain cognitive learning behavior in consumers online (novelty). Previous studies have not examined the cognitive learning behavior model (Cognitive Learning Behavior). The problems that will be examined are 1) what and how to Recursive Cognitive Learning Behavior in online consumers, 2) What is the role of cognitive learning behavior in online consumer purchasing decisions. The specific purpose of this study is to test and verify models that describe cognitive learning behavior (Cognitive Learning Behavior) in online consumers. The urgency of the research is to enrich the knowledge of marketing management especially consumer behavior by finding new concepts and models of "Cognitive Learning Behavior" that underlie online consumer behavior.

\section{Literature review}

In understanding online consumer purchasing decisions, the theoretical approach used is the theory of consumer behavior (Kotler and Keller, 2007) which states that purchasing decisions as part of consumer behavior are influenced by the presence of marketing stimuli, one of which is promotion or communicator. Setiadi (2008) states that marketing stimuli are any communication or physical stimuli designed to influence consumers (Lin et al., 2016). Assael (1992: 128) states that every form of communication is physical, visual, or verbal communication that can affect the response of individuals.

The theory underlying online promotion marketing is the theory of Kotler and Armstrong (2008) which states that promotion is an activity that communicates the benefits of a product and persuades the target consumer to buy the product (Basuki et al., 2017). Online marketing is an application of the application of information technology and the internet in the field of marketing promotion, therefore it is closely related to the theory of technology adoption or TAM (Technology Acceptance Models) by Davis (1989) which states that an application of information systems, user acceptance of the information system strongly influenced by perceptions of ease of use and perceived usefulness (Ardyanto et al., 2015; Bechmann and Lomborg, 2013; Koufaris, 2002; Priambodo and Prabawani, 2016).

Kotler and Keller (2007) require that consumer decision processes are influenced by consumer psychological factors, one of which is learning. The concept of consumer learning that is online and offline has fundamental differences. Bloom's taxonomy theory states that learning covers 3 domains, namely cognitive (mind), affective (attitude), psychomotor (skill), this learning theory applies to offline buying behavior, but in online purchasing Bloom's taxonomic theory does not apply because psychomotor cannot walk in the online domain because in the online realm there is no physical form. Therefore, in understanding the online purchasing theory used is the theory of cognitive learning (mind) or affective learning.

The online marketing stimulus will affect consumers' affective abilities and affective learning processes occur. Affective learning is an ability that prioritizes feelings, emotions, and reactions that are different from reasoning (Gagne, 1977). In this affective domain, consumers will provide an emotional response from marketing stimulus (Ballantine and Fortin, 2009; Björk, 2010; Gumulya and Nastasia , 2015). Online consumers who have been emotionally affected have an interest in a product (Hatane et al., 2016; Herjanto et al., 2015).

And, this is where the cognitive learning process takes place. Cognitive learning theory states learning is a process that involves cognitive aspects of aspects of knowledge, reasoning, or thought. The mind of consumers will receive information about products, brands and so on, then it will be processed by the human brain. In this cognitive realm, information from online marketing will increase knowledge, understanding, application, analysis, synthesis and evaluation of consumers of a product.

In the mind process consumers can recall consumer experiences when dealing with these products so that the theory of CEM (Customers Experience Management) can be involved as an approach to understanding consumer experience preferences (Meyer and Schwager,2007). In detail the theoretical approach in research can be presented in the scheme below: 


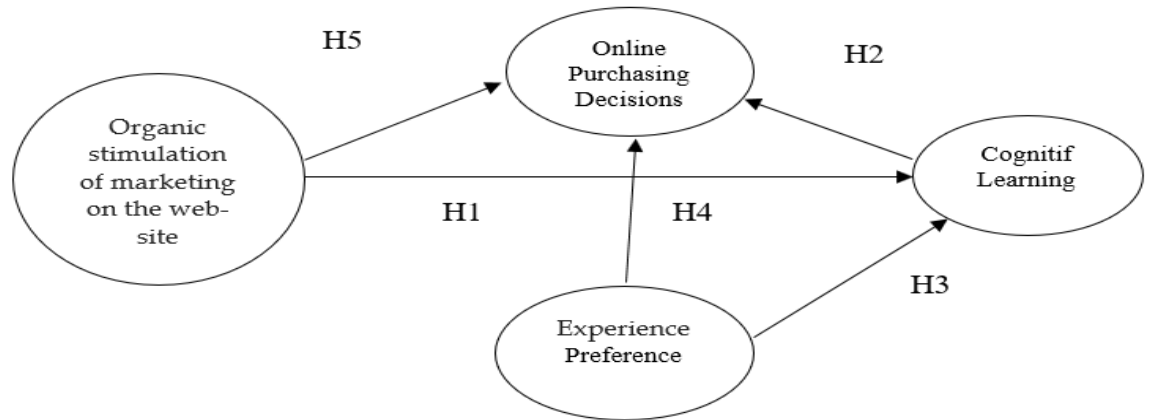

Fig. 1:Conceptual Framework of the Recursive Model of Behavior of Consumer Cognitive Learning Online.

Based on the model in Figure 1 above, the hypotheses that can be tested are as follows

Table 2:The Hypothesis to Be Tested

\begin{tabular}{ll}
\hline Hypothesis & Statement \\
\hline H1 & Organic stimulation of marketing on the website has a significant effect on cognitive learning \\
H2 & Cognitive learning has a significant effect on online purchasing decisions \\
H3 & Experience preferences have a significant effect on cognitive learning \\
H4 & Experience preferences have a significant effect on online purchasing decisions \\
H5 & Organic stimulation of marketing on the website has a significant effect on online purchasing decisions \\
\hline
\end{tabular}

\section{Research method}

This research is a survey with a quantitative approach. The data used are primary data, with research instruments in the form of lift $/$ questionnaire. The questionnaire was distributed online. The subjects of this study are individuals namely online consumers. The population of this study is online consumers, where online consumers are consumers who have accounts with e-commerce companies (Matahari.mall, bukalapak, tokopedia, shoppee, Zilingo) with dominant fashion products.

Sampling technique with Convenience Sampling. The number of samples obtained in this study is 200. The variables involved in this study are online marketing stimulus, cognitive learning, experience interference and online purchasing decisions. In the independent variable research is organic stimulus, online marketing on a web. Methods of data analysis with (1) test data quality instruments (validity and reliability), (2) Analysis of Descriptive Statistics and (3) Analysis of Models by SEM dissertation by testing hypotheses.

\section{Result and discussion}

\subsection{Descriptive statistics characteristics of respondents}

In this study it was found that the total number of respondents was 200 . The total female respondents were $71.1 \%$. Respondents in this study were dominated by age $19-26$ years at $88.6 \%$. The most dominant type of product in online purchases is clothing at $37.8 \%$. Descriptions of respondents supporting the survey of the Snapcart Research Institute (2018) which states that the majority of consumers shopping online in Indonesia are women with a total reaching 65\%, millennial and most transactions for fashion products.

\subsection{Descriptive statistics of respondent satisfaction}

Table 3:Characteristics of Respondents About Online Purchasing Satisfaction

\begin{tabular}{lll}
\hline Online Purchasing Satisfaction & Sum & Percentage \\
\hline Very satisfied & 10 & $5 \%$ \\
satisfied & 150 & $75,1 \%$ \\
Less Satisfied & 38 & $18,8 \%$ \\
Not Satisfied & 2 & $1 \%$ \\
SUM & 200 & $100 \%$ \\
\hline
\end{tabular}

Source: Primary data processed, 2019.

Table 3 shows that the majority of respondents $(75,1 \%)$ were satisfied to make online purchases on e-commerce.

\subsection{Descriptive statistics of respondents' attitudes}

Table 4:Respondents' Responses About Organic Stimulation of Marketing on the Website (X1)

Indicator Organic stimulation of Marketingon the Website

Color scheme

Music Scheme

Picture Scheme

Desain Scheme

Interaktive

Speed of information access

Form of information

Consumer Opinion

Average

Source: Primary data processed, 2019.

\begin{tabular}{llllllll} 
& SS & S & N & TS & STS & $\Sigma$ & Average \\
& 5 & 4 & 3 & 2 & 1 & & \\
X11 & 25 & 95 & 69 & 12 & 0 & 736 & 3,66 \\
X12 & 17 & 63 & 98 & 23 & 0 & 677 & 3,37 \\
X13 & 45 & 114 & 39 & 3 & 0 & 804 & 4,00 \\
X14 & 40 & 109 & 46 & 6 & 0 & 789 & 3,91 \\
X15 & 40 & 98 & 58 & 4 & 1 & 775 & 3,86 \\
X16 & 69 & 95 & 33 & 4 & 0 & 832 & 4,14 \\
X17 & 64 & 94 & 39 & 4 & 0 & 821 & 4,08 \\
X18 & 52 & 108 & 40 & 1 & 0 & 814 & 4,05 \\
& & & & & & & 3,89 \\
\hline
\end{tabular}


Table 4 shows that the respondent's response to the marketing stimulus has an average value of the overall indicator of 3.89 (Good). The indicator with the highest average value is the speed of information access being the most dominant indicator to explain the marketing stimulus on the website

Table 5:Respondents' Responses About Experience Preferences (X2)

\begin{tabular}{|c|c|c|c|c|c|c|c|c|}
\hline \multirow{2}{*}{ IndicatorExperience Preferences } & & SS & $\mathrm{S}$ & $\mathrm{N}$ & TS & STS & \multirow{2}{*}{$\Sigma$} & \multirow[t]{2}{*}{ Average } \\
\hline & & 5 & 4 & 3 & 2 & 1 & & \\
\hline Touch, vision, sound, create experiences & $\mathrm{X} 21$ & 30 & 115 & 52 & 4 & 0 & 774 & 3,85 \\
\hline Feeling and emotional involvement & $\mathrm{X} 22$ & 27 & 101 & 71 & 2 & 0 & 756 & 3,76 \\
\hline Past experience with the product & $\mathrm{X} 23$ & 34 & 109 & 55 & 3 & 0 & 777 & 3,87 \\
\hline Intellectual involvement in experience & X44 & 23 & 100 & 74 & 4 & 0 & 745 & 3,71 \\
\hline Average & & & & & & & & 3,79 \\
\hline
\end{tabular}

Source: Processed primary data, 2019.

Table 5 shows that respondents' responses to experience preferences have an average value category of the overall indicator of 3.79 (Good). The indicator with the highest average value is that past experience is the most dominant indicator that explains experience preference

Table 6: Respondents' Response to Cognitive Learning (Y1)

\begin{tabular}{|c|c|c|c|c|c|c|c|c|}
\hline \multirow{2}{*}{\multicolumn{2}{|c|}{ IndicatorCognitive Learning }} & \multirow{2}{*}{$\begin{array}{l}\text { SS } \\
5\end{array}$} & \multirow[t]{2}{*}{$\mathrm{S}$} & \multirow{2}{*}{$\begin{array}{l}\mathrm{N} \\
3\end{array}$} & \multirow{2}{*}{$\begin{array}{l}\text { TS } \\
2\end{array}$} & \multirow{2}{*}{$\begin{array}{l}\text { STS } \\
1\end{array}$} & \multirow{2}{*}{$\Sigma$} & \multirow[t]{2}{*}{ Average } \\
\hline & & & & & & & & \\
\hline Knowledge involvement & Y11 & 32 & 131 & 35 & 3 & 0 & 795 & 3,96 \\
\hline Product understanding involvement & Y12 & 25 & 137 & 36 & 1 & 0 & 789 & 3,93 \\
\hline Engagement of previous purchase deci & sY13 & 19 & 111 & 67 & 4 & 0 & 748 & 3,72 \\
\hline Engagement of analytical skills & Y14 & 17 & 119 & 84 & 1 & 0 & 755 & 3,76 \\
\hline Involvement in synthesis capabilities & Y15 & 12 & 100 & 82 & 7 & 0 & 720 & 3,58 \\
\hline Engagement evaluation capabilities & Y16 & 29 & 107 & 58 & 7 & 0 & 761 & 3,79 \\
\hline Average & & & & & & & & 3,79 \\
\hline
\end{tabular}

Source: Processed primary data, 2019.

Table 6 shows that respondents respond to cognitive learning, which has a good average value category in each indicator. The average value of the overall indicator is 3.79 (rather good). Knowledge involvement indicators are the most influential statements for respondents in cognitive learning (Y2).

Table 7:Respondents' Responses to Online Purchasing Decisions (Y2)

\begin{tabular}{|c|c|c|c|c|c|c|c|c|}
\hline \multirow[b]{2}{*}{ IndicatorOnline Purchasing Decisions } & & SS & $\mathrm{S}$ & \multirow{2}{*}{$\begin{array}{l}\mathrm{N} \\
3\end{array}$} & \multirow{2}{*}{$\begin{array}{l}\text { TS } \\
2\end{array}$} & STS & \multirow{2}{*}{$\Sigma$} & \multirow[b]{2}{*}{ Average } \\
\hline & & 5 & 4 & & & 1 & & \\
\hline Product stability in online purchases & Y21 & 29 & 101 & 68 & 3 & 0 & 759 & 3,78 \\
\hline Online buying habits & Y22 & 12 & 84 & 71 & 14 & 0 & 698 & 3,47 \\
\hline Satisfaction and recommend to people & Y23 & 32 & 84 & 71 & 14 & 0 & 737 & 3,67 \\
\hline Product satisfaction and repurchase & Y24 & 26 & 88 & 66 & 21 & 0 & 722 & 3,59 \\
\hline Average & & & & & & & & 3,63 \\
\hline
\end{tabular}

Source: Processed primary data, 2019.

Based on table 7 shows that the responses of respondents to online purchasing decisions, which have an average value of the overall indicator of 3.63 (rather good). The indicator of product stability on online purchases is the most dominant statement in explaining online purchasing decisions.

Overall the indicators in this study provide good responses. The average value of each variable also shows good results. Thus the question items on the questionnaire can be used to understand the respondents' perceptions of the subject matter in the study.

\subsection{Description of cognitive learning behavior}

Based on the theoretical perspective, online consumer behavior is a product of cognitive learning (Hasan, 2012; Kim and Lennon, 2010; Li, 2007; Steils and Decrop, 2018). Online consumers do cognitive learning starting from the stimulus that comes from online marketing from the web in the form of color, image, design, sound and so on that refers to a particular product / brand (Gaspar, 2017; Joy et al., 2009; Kim and Lennon, 2013; Lorenzo-Romero et al., 2016; Pluzinski and Qualls, 1975). Information about the product / brand is accepted by cognition (mind). Information processing about a product / brand on consumer cognition includes the process of encoding information (encoding), then storing information (storage) and retrieving information that has been stored in consumer memory (retrival) (Tolman, 2005; Aljukhadar, 2009; Martin and Dahlen, 2005)). Preference of past experience related to consumer long-term memory relationship to a product / brand, will be revealed again in the memory (cognition) of consumers.

\subsection{Data quality test}

Data quality is tested by the instrument validity test (reliability) and reliability (reliability). Test Validity is a test that shows the extent to which the measuring device used is able to measure what you want to measure rather than measure the other. Validity tests have criteria that must be met. That is, loading factor is required significantly and standardized loading estimate is required 50.05 . Table 7 below shows that all indicators meet valid criteria 
Table 8:Test Result Validity for Indicator Items

\begin{tabular}{|c|c|c|c|c|c|c|c|}
\hline Variabel & $\begin{array}{l}\text { Relationship } \\
\text { ofVariabel }\end{array}$ & Estimate & $\begin{array}{l}\text { Standardize } \\
\text { Regrestion Weight }\end{array}$ & S.E. & C.R. & $\mathrm{P}$ & Resume \\
\hline \multirow{4}{*}{$\begin{array}{l}\text { Organic stimulation } \\
\text { of Marketing on the } \\
\text { Website (X1) }\end{array}$} & $\mathrm{X} 11 \leftarrow \mathrm{X} 1$ & $1 ., 000$ & 0,588 & & & & Valid \\
\hline & $\mathrm{X} 13 \leftarrow \mathrm{X} 1$ & 1,182 & 0,776 & 0,154 & 7,695 & $* * *$ & Valid \\
\hline & $\mathrm{X} 14 \leftarrow \mathrm{X} 1$ & 1,366 & 0,842 & 0,176 & 7,775 & $* * *$ & Valid \\
\hline & $\mathrm{X} 15 \leftarrow \mathrm{X} 1$ & 0,954 & 0,562 & 0,152 & 6,273 & $* * *$ & Valid \\
\hline \multirow{4}{*}{$\begin{array}{l}\text { Cognitive } \\
\text { Learning(Y1) }\end{array}$} & $\mathrm{Y} 11 \leftarrow \mathrm{Y} 1$ & 0,879 & 0,643 & 0,138 & 6,375 & $* * *$ & Valid \\
\hline & $\mathrm{Y} 12 \leftarrow \mathrm{Y} 1$ & 0,674 & 0,548 & 0,119 & 5,642 & $* * *$ & Valid \\
\hline & $\mathrm{Y} 14 \leftarrow \mathrm{Y} 1$ & 0,763 & 0,609 & 0,124 & 6,128 & $* * *$ & Valid \\
\hline & $\mathrm{Y} 16 \leftarrow \mathrm{Y} 1$ & 1,000 & 0,654 & & & $* * *$ & Valid \\
\hline & $\mathrm{X} 21 \leftarrow \mathrm{X} 2$ & 1,333 & 0,773 & 0,214 & 6,234 & $* * *$ & Valid \\
\hline Experience & $\mathrm{X} 22 \leftarrow \mathrm{X} 2$ & 1,094 & 0,631 & 0,181 & 6,048 & $* * *$ & Valid \\
\hline \multirow[t]{3}{*}{ Preference (X2) } & $\mathrm{X} 23 \leftarrow \mathrm{X} 2$ & 0,913 & 0,519 & 0,170 & 5,357 & $* * *$ & Valid \\
\hline & $\mathrm{X} 24 \leftarrow \mathrm{X} 2$ & 1,000 & 0,573 & & & $* * *$ & Valid \\
\hline & $\mathrm{Y} 21 \leftarrow \mathrm{Y} 2$ & 0,698 & 0,665 & 0,074 & 9,453 & $* * *$ & Valid \\
\hline Online Purchasing & $\mathrm{Y} 22 \leftarrow \mathrm{Y} 2$ & 0,988 & 0,861 & 0,080 & 12,367 & $* * *$ & Valid \\
\hline Decisions (Y2) & $\mathrm{Y} 23 \leftarrow \mathrm{Y} 2$ & 0,978 & 0,792 & 0,085 & 11,535 & $* * *$ & Valid \\
\hline
\end{tabular}

Source: Processed primary data, 2019.

Reliability is a test that shows the extent to which the stability and consistency of the measuring device used, thus providing relatively consistent results if the measurement is repeated. Testing Reliability with the Cronbach Alpha Test has met the criteria if the Cronbach Alpha Test is $>0.7$.

Table 9:Result ofReliability Test

\begin{tabular}{|c|c|c|c|}
\hline Nama Variable & & Cronbach Alpha & Result \\
\hline Organic stimulation of Marketingon the Website & $\mathrm{X} 1$ & 0,781 & Reliable \\
\hline Cognitive Learning & Y1 & 0,772 & Reliable \\
\hline Experience Preference & $\mathrm{X} 2$ & 0,717 & Reliable \\
\hline Online Purchasing Decisions & Y2 & 0,858 & Reliable \\
\hline
\end{tabular}

Source: Processed primary data, 2019.

\subsection{Evaluation of normality}

Table 10: Data of Normality

\begin{tabular}{|c|c|c|c|c|c|c|}
\hline Variable & $\min$ & $\max$ & skew & c.r. & Curtosis & c.r. \\
\hline $\mathrm{X} 21$ & 2,000 & 5,000 &,- 182 & $-1,050$ &,- 070 &,- 201 \\
\hline $\mathrm{X} 22$ & 2,000 & 5,000 & ,162 & ,937 &,- 575 & $-1,659$ \\
\hline $\mathrm{X} 23$ & 2,000 & 5,000 &,- 075 &,- 432 &,- 393 & $-1,135$ \\
\hline $\mathrm{X} 24$ & 2,000 & 5,000 & ,102 & ,588 &,- 428 & $-1,236$ \\
\hline Y24 & 2,000 & 5,000 &,- 159 &,- 917 &,- 559 & $-1,613$ \\
\hline Y23 & 2,000 & 5,000 &,- 055 &,- 319 &,- 596 & $-1,720$ \\
\hline Y22 & 2,000 & 5,000 &,- 231 & $-1,334$ &,- 416 & $-1,201$ \\
\hline Y21 & 2,000 & 5,000 &, 073 & ,420 &,- 530 & $-1,529$ \\
\hline Y16 & 2,000 & 5,000 &,- 192 & $-1,111$ &,- 201 &,- 581 \\
\hline Y15 & 2,000 & 5,000 &,- 052 &,- 299 &,- 204 &,- 589 \\
\hline Y14 & 2,000 & 5,000 & ,022 & ,126 &,- 289 &,- 835 \\
\hline Y12 & 2,000 & 5,000 &,- 169 &,- 978 & ,516 & $-1,490$ \\
\hline Y11 & 2,000 & 5,000 &,- 339 & $-1,957$ & ,648 & $-1,872$ \\
\hline $\mathrm{X} 13$ & 2,000 & 5,000 & ,371 & 2,144 &,- 296 &,- 854 \\
\hline X14 & 2,000 & 5,000 &,- 119 &,- 686 &,- 146 &,- 423 \\
\hline X11 & 2,000 & 5,000 & ,176 & 1,014 &,- 151 &,- 435 \\
\hline Multivariate & & & & &,- 599 &,- 223 \\
\hline
\end{tabular}

In the table above, the valuesof cr and kurtosis have been obtained in the range of $-2.58-2.58$. And the value of cr on multivariate is 0.113 and is at $-2.58-2.58$, which means that the data is normally distributed, so the data in this study can be analyzed using Structural Equation Modeling (SEM).

\subsection{Structural equation modelling (SEM)}

Analysis of structural equation modeling is used to find out the structural relationship between variables. Structural relations between variables are tested for their suitability with Goodness of fit. The results of the analysis of structural equation modeling in this study can be seen in the picture as follows:

Using the Basic Model analysis, the Goodness of fit size is obtained as follows: 
Table.11:Goodness of Fit with Basic Model Analysis

\begin{tabular}{lllll}
\hline & Indicator & Value & Criteria & Result \\
\hline 1 & Chi-kuadrat & 216,988 & $>=167,52$ & Good \\
2 & GFI & 0,893 & $>=0,90$ & Marginal \\
3 & RMSEA & 0,068 & $<=0,08$ & Good \\
4 & AGFI & 0,855 & $>=0,90$ & Marginal \\
5 & TLI & 0,900 & $>=0,90$ & Good \\
\hline Source: 2019 data exercise.
\end{tabular}

The results of the model evaluations that are based on the Goodness of Fit criteria above generally show the conclusion that the model is quite good (marginal means still acceptable). The model is quite good, meaning the hypothesized model is in conformity with the data obtained in factual terms.

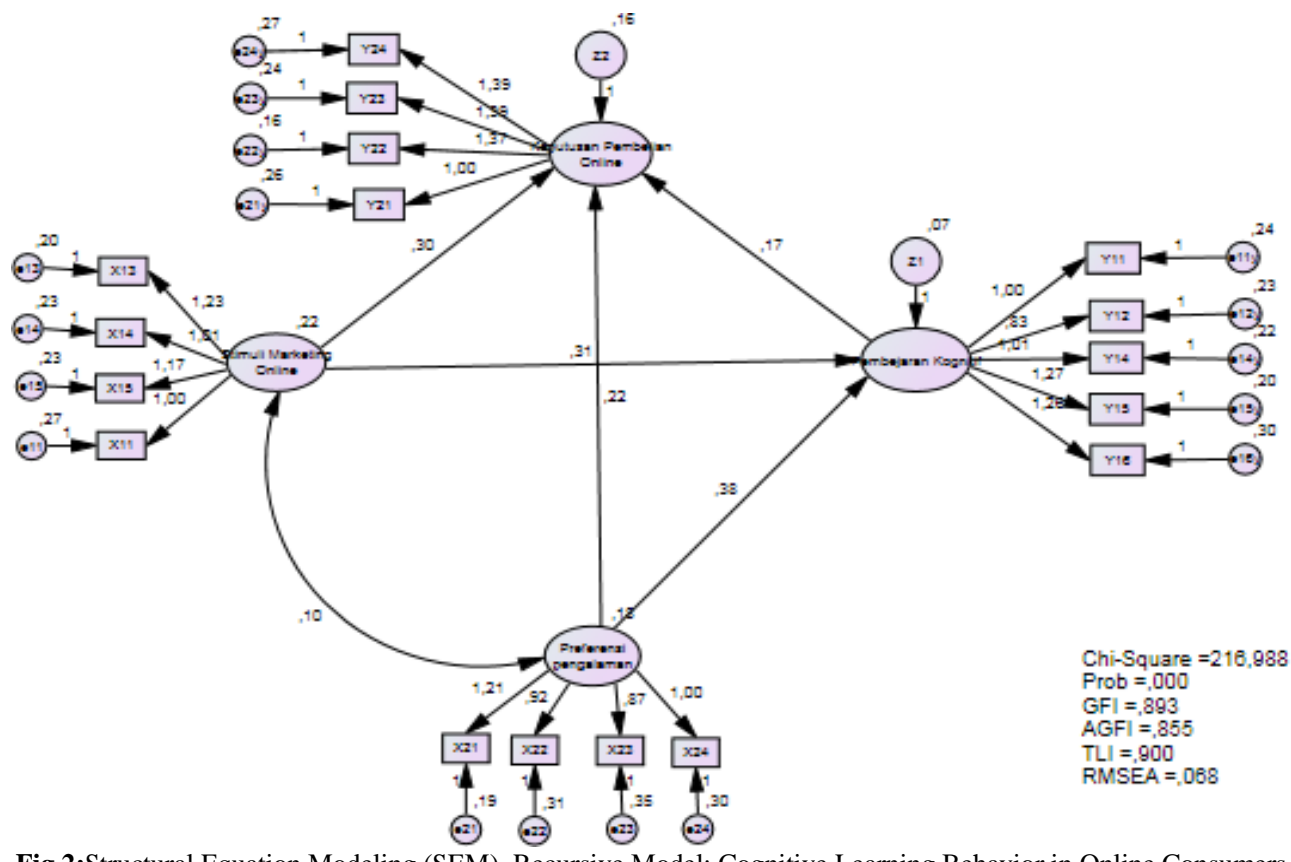

Fig.2: Structural Equation Modeling (SEM), Recursive Model: Cognitive Learning Behavior in Online Consumers

\subsection{Hypothesis testing}

This hypothesis test is done to find out whether or not the effect of exogenous variables on endogenous variables. This hypothesis can be accepted if the prob value is $(\mathrm{P}) \leq 0.05$. The results of this hypothesis test can be seen in the table as follows:

Table12:Regression Weights: (Group Number 1 - Default Model)

\begin{tabular}{|c|c|c|c|c|c|c|c|}
\hline & & & Estimate & S.E. & C.R. & $\mathrm{P}$ & Label \\
\hline $\mathrm{Y} 1$ & $<--$ & $\mathrm{X} 1$ & 309 & ,083 & 3,731 & $* * *$ & par_17 \\
\hline Y1 & $<---$ & $\mathrm{X} 2$ & ,377 & ,099 & 3,801 & $* * *$ & par_18 \\
\hline $\mathrm{Y} 2$ & $<--$ & $\mathrm{Y} 1$ & ,166 & ,155 & 1,070 & ,284 & par_10 \\
\hline $\mathrm{Y} 2$ & $<---$ & $\mathrm{X} 1$ &, 300 &, 109 & 2,743 & ,006 & par_16 \\
\hline $\mathrm{Y} 2$ & $<---$ & $\mathrm{X} 2$ & ,221 & ,130 & 1,702 & ,089 & par_19 \\
\hline X11 & $<--$ & $\mathrm{X} 1$ & 1,000 & & & & \\
\hline $\mathrm{X} 15$ & $<--$ & $\mathrm{X} 1$ & 1,165 & ,132 & 8,816 & $* * *$ & par_1 \\
\hline X14 & $<---$ & $\mathrm{X} 1$ & 1,014 &, 121 & 8,387 & $* * *$ & par_2 \\
\hline Y11 & $<---$ & $\mathrm{Y} 1$ & 1,000 & & & & \\
\hline Y12 & $<--$ & $\mathrm{Y} 1$ &, 830 & ,133 & 6,245 & $* * *$ & par_3 \\
\hline Y15 & $<---$ & $\mathrm{Y} 1$ & 1,271 &, 167 & 7,592 & $* * *$ & par_4 \\
\hline Y16 & $<---$ & $\mathrm{Y} 1$ & 1,264 &, 178 & 7,110 & $* * *$ & par_5 \\
\hline Y14 & $<---$ & $\mathrm{Y} 1$ & 1,005 & ,145 & 6,918 & $* * *$ & par_6 \\
\hline Y21 & $<---$ & $\mathrm{Y} 2$ & 1,000 & & & & \\
\hline Y22 & $<---$ & $\mathrm{Y} 2$ & 1,373 &, 134 & 10,220 & $* * *$ & par_7 \\
\hline Y23 & $<---$ & $\mathrm{Y} 2$ & 1,393 & ,142 & 9,815 & $* * *$ & par_8 \\
\hline Y24 & $<--$ & $\mathrm{Y} 2$ & 1,387 & ,144 & 9,619 & $* * *$ & par_9 \\
\hline X24 & $<---$ & $\mathrm{X} 2$ & 1,000 & & & & \\
\hline $\mathrm{X} 23$ & $<---$ & $\mathrm{X} 2$ & ,865 & ,148 & 5,838 & $* * *$ & par_11 \\
\hline $\mathrm{X} 22$ & $<--$ & $\mathrm{X} 2$ & ,925 & ,148 & 6,242 & $* * *$ & par_12 \\
\hline $\mathrm{X} 21$ & $<---$ & $\mathrm{X} 2$ & 1,210 & ,168 & 7,209 & $* * *$ & par_13 \\
\hline $\mathrm{X} 13$ & $<---$ & $\mathrm{X} 1$ & 1,225 &, 134 & 9,113 & $* * *$ & par_15 \\
\hline
\end{tabular}

The value of Regression Weights in table 12 states that the effect of independent variables on the dependent variable has a positive and significant effect. The results of loading factors in table 13 can be presented as follows: 
Table.13:Loading Factor in Basic Model

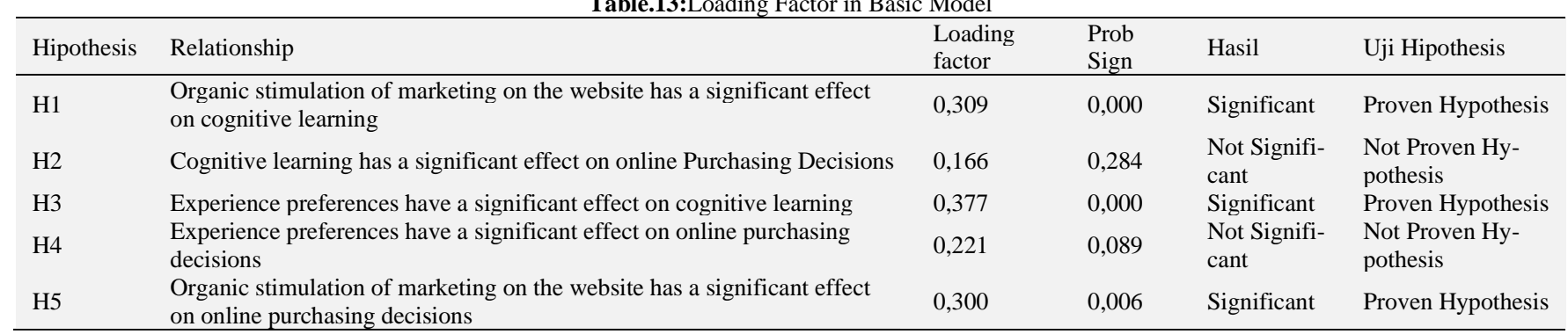

\subsection{Coefficient of determination}

The coefficient of determination in the hypothesized model was obtained 0.268 or $26.8 \%$. Based on the coefficient of determination states that the contribution of independent variables to the dependent variable is $18 \%$ and the remaining dependent variables are influenced by other variables not examined.

\subsection{Discussion}

This study successfully proved that marketing stimulus has a significant effect on cognitive learning. The results of this study are consistent with the research conducted by Kotler and Keller (2007) which states that marketing stimulus will influence consumer behavior This study successfully proved that cognitive learning has a significant effect on purchasing decisions. The results of this study are consistent with the research conducted by Kotler and Keller (2007) which states that marketing stimulus will influence consumer behavior This study succeeded in proving that experience preferences had a significant effect on cognitive learning. The results of this study are consistent with the research conducted by Kotler and Keller (2007) which states that psychological consumers including consumer experience in marketing will influence consumer behavior.

This study has not been successful in proving that experience preferences have a significant effect on online consumer purchasing decisions. The results of this study are consistent with the research conducted by Kotler and Keller (2007) which states that psychological consumers including consumer experience in marketing will influence consumer behavior.

This study successfully proved that marketing stimulus has a significant effect on online purchasing decisions. The results of this study are consistent with the research conducted by Kotler and Keller (2007) which states that marketing stimulus will influence consumer behavior.

\section{Conclusions and suggestions}

\subsection{Conclusion}

This study aims to prove the concept that online consumer purchasing decisions are strongly influenced by consumer learning factors. The main theories underlying this research are the theory of consumer behavior and learning theory. Learning theory is used to analyze online consumer behavior as a consumer learner with a mix of (crossing) learning theories of behavior and cognitive learning theory. Combination (crossing) between behavioral learning theory, cognitive is called cognitive learning behavior (cognitive learning behavior). This research is a survey. The data used are primary data, with the research instrument in the form of a questionnaire. The subjects of this study are individuals namely online consumers. Online consumers in this research are millennial generation who have made online purchases on one of the e-commerce sites in Indonesia (Matahari.mall, bukalapak, tokopedia, shoppee, Zilingo, Zalora) with this type of product is fashion. In this study 201 respondents were selected.

The study consisted of independent variables (web marketing stimulus), dependent variables (online purchasing decisions), and mediating variables (cognitive learning). Convenience sampling sampling technique is a sampling method where sampling is based on the availability of elements and the ease of obtaining them. Samples are taken or selected because the sample is in the right place and time. Data analysis methods with 1) test data quality instruments (validity and reliability), 2) Analysis of Descriptive Statistics and 3) Model Analysis with SEM. The results showed that 1) Organic stimulation of marketing on the website had a positive and significant effect on cognitive learning, 2)experience preference had a positive and significant effect on cognitive learning, 3)cognitive learning had a positive and not significant effect on online purchasing decisions, 4) experience preference had a positive and not significant effect on online purchasing decisions, 5)Organic stimulation of marketing on the website had a positive and significant effect on online purchasing decisions.

\subsection{Suggestion}

First, this study provides recommendations for subsequent research to examine the effect of cognitive learning on online consumer purchasing decisions, because the results of the study show evidence that cognitive learning has no significant effect on purchasing decisions.

Second, this study provides recommendations for subsequent research to examine the influence of experience preferences on online consumer purchasing decisions, because the results of the study show evidence that experience preferences have no significant effect on purchasing decisions

Third, this study provides recommendations for the next study to examine the effect of affective learning on online consumer purchasing decisions, because research has not provided evidence of the relationship of affective learning to online consumers 


\section{References}

[1] Abarbanel, B., Bernhard, B., Singh, A. K., \& Lucas, A. (2015). Impact of virtual atmospherics and functional qualities on the online gambler's experience. Behaviour and Information Technology, 34(10), 1005-1021. http://doi.org/10.1080/0144929X.2015.1046930.

[2] Abideen, Z.-U., \& Saleem, S. (2012). Effective advertising and its influence on consumer buying behavior. European Journal of Business and Management, 3(3), 114-119.http://doi.org/10.5897/JAERD12.088.

[3] AfandySrikandiKumadjiFransiscaYaningwati, T., Kunci, K., \& dan Keputusan Pembelian, K. (2014). Pengaruhfaktorpsikologisterhadapkeputusanpembelian (Survei pada MahasiswaFakultasIlmuAdministrasiJurusanAdministrasiBisnis Universitas Brawijaya Malang yang MemutuskanMembeli Handphone Merek Nokia). JurnalAdministrasiBisnis, 15(1).

[4] Affecting, F., Decision, C., Sector, I. R., Behavior, C. C., \& Behavior, R. C. (2009). Factors influencing satisfaction and loyalty in online shopping: an integrated model. Online Information Review, 33(3), 458-475. http://doi.org/10.1108/14684520910969907.

[5] Affecting, F., Decision, C., Sector, I. R., Behavior, C. C., \& Behavior, R. C. (2011). The moderating effect of customer perceived value on online shopping behaviour. Online Information Review (Vol. 35). http://doi.org/10.1108/14684521111151414.

[6] Akbar, R. M. (2014). Pengaruhadanyateknologi online shop terhadaptingkahlakukonsumen. Management Bachelor Programe, School of Economics and Business. Retrieved from http://rizkiamiftah.blogspot.com/2014/11/dampak-teknologi-online-shopterhadap.html.

[7] Al-Jabari, M., Norezam Othman, S., \&Kamariah Nik Mat, N. (2012). Actual Online Shopping Behavior among Jordanian Customers. American Journal of Economics, 2(4),125-129. http://doi.org/10.5923/j.economics.20120001.28

[8] Aljukhadar, M. (2009). E-customization: Research and applications from the cognitive learning theory. Handbook of Research in Mass Customization and Personalization.http://doi.org/10.1142/9789814280280 0013.

[9] Anggraeni, Penia; Madiawati, P. N. (2016). PengaruhKepercayaan dan KualitasInformasiterhadap Keputusan Pembeliansecara Online pada Situs www.Traveloka.com. EProceeding of Management, 3(2), 1880-1887.

[10] Ardianto Kusuma. (2016). AnalisisFaktor-Faktor Yang BerpengaruhTerhadap Keputusan PembelianSecara Online Di Website Tokopedia (StudiKasus pada Mahasiswa di Universitas Islam Indonesia). JurnalEkonomi, 1-22.

[11] Ardyanto, D., Susilo, H., \&Riyadi. (2015). PengaruhKemudahan dan KepercayaanMenggunakan E-CpmmerceTerhadap Keputusan Pembelian Online (Survei Pada Konsumenwww.petersaysdenim.com). PengaruhKemudahan Dan KepercayaanMenggunakan E-Commerce Terhadap Keputusan Pembelian Online, 22(1), 1-8.

[12] Azzadina, I., Huda, A. N., Pamatang, C., \&Sianipar, M. (2012). Understanding Relationship between Personality Types, Marketing-mix Factors, and Purchasing Decisions. Procedia -Social and Behavioral Sciences International Congress on Interdisciplinary Business and Social Science IrnaAzzadina et Al. Procedia -Social and Behavioral Sciences, 65(65), 352-357. http://doi.org/10.1016/j.sbspro.2012.11.133.

[13] Badrinarayanan, V., Becerra, E. P., Kim, C. H., \& Madhavaram, S. (2012). Transference and congruence effects on purchase intentions in online stores of multi-channel retailers: Initial evidence from the U.S. and South Korea. Journal of the Academy of Marketing Science, 40(4), 539-557. http://doi.org/10.1007/s11747-010-0239-9.

[14] Bagozzi, R. P., \& Dholakia, U. M. (2002). Intentional social action in virtual communities. Journal of Interactive Marketing, 16(2), 2-21. http://doi.org/10.1002/dir.10006.

[15] Ballantine, P. W., \& Fortin, D. R. (2009). The effects of interactivity and product information on consumers' emotional responses to an online retail setting. International Journal of Internet Marketing and Advertising, 5(4), 260.http://doi.org/10.1504/ijima.2009.027810.

[16] Basuki Cahyono, DheaseyAmboningtyas, Andi Tri Haryono, D. M. (2017) Bayton, J. A. (1958). Motivation, Cognition, Learning: Basic Factors in Consumer Behavior. Journal of Marketing, 22(3), 282-289. http://doi.org/10.2307/1247119.

[17] Bechmann, A., \& Lomborg, S. (2013). Applying the technology acceptance model and flow theory to online consumer behavior. New Media and Society, 15(5), 765-781. http://doi.org/10.1287/isre.13.2.205.83.

[18] Björk, P. (2010). Atmospherics on tour operators' websites: Website features that stimulate emotional response. Journal of Vacation Marketing 16(4), 283-296.http://doi.org/10.1177/1356766710372243.

[19] Bloom, B. (1956). A Taxonomy of Cognitive Objectives. In A Taxonomy of Cognitive Objectives.

[20] Blunch, N. J. (2012). SEM-Analysis and AMOS. Introduction to Structural Equation Modelling Using SPSS and AMOS, 74-102. http://doi.org/10.1007/BF00213440.

[21] Brakus, J. J., Schmitt, B. H., \&Zarantonello, L. (2009). Brand Experience: What Is It? How Is It Measured? Does It Affect Loyalty? Journal of Marketing, 73(3), 52-68.http://doi.org/10.1509/jmkg.73.3.52.

[22] Caraka, G. P., \&Rachmawati, I. (2015). PerananKarakteristik Dan PsikologiKonsumenTerhadap Keputusan PembelianKembaliProdukPakaianMe-

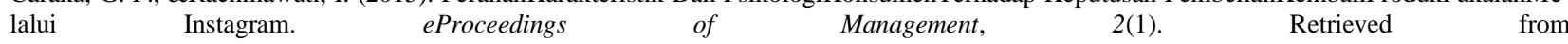
http://libraryeproceeding.telkomuniversity.ac.id/index.php/management/article/view/1119/1072.

[23] Chen, L. S. L. (2010). The impact of perceived risk, intangibility and consumer characteristics on online game playing. Computers in Human Behavior, 26(6), 1607-1613.http://doi.org/10.1016/j.chb.2010.06.008.

[24] Childers, T. L., Carr, C. L., Peck, J., \& Carson, S. (2001). Hedonic and utilitarian motivations for online retail shopping behavior. Journal of Retailing, 77(4), 511-535.http://doi.org/10.1016/S0022-4359(01)00056-2.

[25] Cho, Y., Im, I., Hiltz, R., \&Fjermestad, J. (2002). The Effects of Post-Purchase Evaluation Factors on Online vs. Offline Customer Complaining Behavior: Implications for Customer Loyalty. Advances in Consumer Research, 29(1), 318-326. http://doi.org/10.16953/deusbed.74839.

[26] Coviello, N., Milley, R., \&Marcolin, B. (2001). Understanding IT-enabled interactivity in contemporary marketing. Journal of Interactive Marketing, 15(4), 18-33.http://doi.org/10.1002/dir.1020.

[27] Cugelman, B. (2010). Online Social Marketing: Website Factors in Behavioural Change. Marketing Journal.

[28] Cui, X., Lai, V. S., \& Lowry, P. B. (2016). How do bidders' organism reactions mediate auction stimuli and bidder loyalty in online auctions? The case of Taobao in China.Information and Management, 53(5), 609-624. http://doi.org/10.1016/j.im.2016.01.00.

[29] Cummins, S., Peltier, J. W., Schibrowsky, J. A., \&Nill, A. (2014). Consumer behavior in the online context. Journal of Research in Interactive Marketing, 8(3), 169-202.http://doi.org/10.1108/JRIM-04-2013-0019.

[30] Dajan, A. (1976). PengantarMetodeStatistikJilid II. In PengantarMetodeStatistikJilid II.

[31] Darley, W. K. (2010). Guest editorial: The interaction of online technology on the consumer shopping experience. Psychology and Marketing, 27(2), 91-93. http://doi.org/10.1002/mar.20321.

[32] Davis, F. D. (1989). Perceived Usefulness, Perceived Ease of Use, and User Acceptance of Information Technology. MIS Quarterly, $13(3)$, 319. http://doi.org/10.2307/249008 70.

[33] Dewi, N. P. R. A., \&Ardani, I. G. A. K. S. (2016). PengaruhSikap, Norma SubjektifTerhadapNiatBeliUlangProduk Fashion Via Online di Kota Denpasar. E-JurnalManajemenUnud, 5(4), 2637-2664. http://doi.org/2302-8912.

[34] Di Pietro, L., \&Pantano, E. (2012). An empirical investigation of social network influence on consumer purchasing decision: The case of Facebook. Journal of Direct, Data and Digital Marketing Practice, 14(1), 18-29. http://doi.org/10.1057/dddmp.2012.10.

[35] Dobre, C., \& Milovan-Ciuta, A.-M. (2015). Personality influences on online stores customers behavior. EcoForum, 4(1), 69-76.

[36] Edy, I. C., \&Riyanto. (2017). Soft model: Online consumer behavior with social culture as moderating effects. International Journal of Civil Engineering and Technology, 8(10),578-587. Retrieved from https://www.scopus.com/inward/record.uri?eid=2-s2.085037857730\&partnerID=40\&md5=ba491335eebc0ada98647f646291f2aa.

[37] Edy, I. C., \&Tiningrum, E. (2015). Examining the model of the use of facebook effects on individual behavior (A Study to the Students of High Schools in Surakarta City). Researchers World, 6(1), 59-65. Retrieved from http://search.proquest.com/docview/1655116110?accountid=41248. 
[38] Ekasari, N. (2014). PengaruhPromosiBerbasisSosial Media Terhadap Keputusan PembelianProdukJasaPembiayaanKendaraan Pada PT. BFI Finance Jambi. JurnalPenelitian Universitas Jambi Seri Humaniora, 16(2), 81. http://doi.org/10.1017/CBO9781107415324.004.

[39] El-Gohary. (2010). The impact of E-marketing practices on market performance of small business enterprises. An empirical investigation. University of Bradford, (2002), 1-51.http://doi.org/10.1159/000105503.

[40] Fihartini, Y. (2017). persepsiperilakuetis online retail pada kepercayaankonsumen dan niatpembelian online. Prosiding: MembangunEtikaSosialPolitikMenujuMasayarakat Yang Berkeadilan, 218-229.

[41] Furkonudin, Suryadi, E., \&Darmanto. (2016). Evaluasikualitaslayanan website ecommerce blibli.com menggunakanmetodewebqual 4.0 terhadapkeputusanpembelian online. Seminar Nasional Teknologilnformasi Dan Multimedia 2016, 7-12. Retrieved from http://ojs.amikom.ac.id/index.php/semnasteknomedia/article/download/1281/1211.

[42] Furmanski, C., Payton, D., \& Daily, M. (2004). Quantitative evaluation methodology for dynamic, Web-based collaboration tools. In Proceedings of the Hawaii International Conference on System Sciences (Vol. 37, pp. 2117-2126).http://doi.org/10.1109/HICSS.2004.1265331.

[43] Gagne, R. M. (1977). the Conditions of Learning. Journal of School Psychology.

[44] Gaspar, P. (2017). User Preferences Analysis Using Visual Stimuli. In Proceedings of the Eleventh ACM Conference on Recommender Systems RecSys '17 (pp. 436-440).http://doi.org/10.1145/3109859.3120955.

[45] Geetha, V., \& Rangarajan, K. (2016). Consumer Buying Behavior Online - An Indian Perspective. IJCTA, 9(40), 359-367. Retrieved from http://serialsjournals.com/serialjournalmanager/pdf/1493468497.pdf.

[46] Gentile, C., Spiller, N., \&Noci, G. (2007). How to Sustain the Customer Experience: An Overview of Experience Components that Co-create Value with the Customer. European Management Journal, 25(5), 395-410. http://doi.org/10.1016/j.emj.2007.08.005.

[47] Gumulya, D., \&Nastasia, P. (2015). Kajian Teori Emotional Design. JurnalDesain, 3(1),1-20.

[48] Hair, J. F., Black, W. C., Babin, B. J., \& Anderson, R. E. (2010). Multivariate Data.

[49] Hasan, U. (2012). Cognitive Dissonance and Its Impact on Consumer Buying Behaviour.IOSR Journal of Business and Management, 1(4), 7-12. http://doi.org/10.9790/487x-0140712.

[50] HataneSemuel. (2006). DampakResponEmosiTerhadapKecenderunganPerilakuPembelianImpulsifKonsumen Online DenganSumberdaya Yang Dikeluakan Dan OrientasiBelanjaSebagaiVariabelMediasi. JurnalManajemen Dan Kewirausahaan, 8, pp.101-115. Retrieved from http://puslit2.petra.ac.id/ejournal/index.php/man/article/view/16571.

[51] Herjanto, H., Gaur, S. S., \& Yap, S.-F. (2015). Consumer Emotional Responses to Emotional Appeal Advertising Within an Online Social Network Context (pp. 226-233).http://doi.org/10.1007/978-3-319-24184-5 59.

[52] Im, H., Lennon, S. J., \&Stoel, L. (2010). The perceptual fluency effect on pleasurable online shopping experience. Journal of Research in Interactive Marketing, 4(4), 280-295.http://doi.org/10.1108/17505931011092808.

[53] Jalalkamali, M., \&Nikbin, D. (2010). The Effects of Motivation on Purchase Decision. Interdisciplinary Journal of Contemprorary Research in Business, 2(8), 234-246.

[54] Joines, J. L., Scherer, C. W., \&Scheufele, D. A. (2003). Exploring motivations for consumer Web use and their implications for e-commerce. Journal of Consumer Marketing, 20(2-3), 90-108. http://doi.org/10.1108/07363760310464578.

[55] Joy, A., Sherry, J., Venkatesh, A., \& Deschenes, J. (2009). Perceiving images and telling tales: A visual and verbal analysis of the meaning of the internet. Journal of Consumer Psychology, 19(3), 556-566. http://doi.org/10.1016/j.jcps.2009.05.013.

[56] Kang, Y. S., \& Kim, Y. J. (2006). Do visitors' interest level and perceived quantity of web page content matter in shaping the attitude toward a web site? Decision Support Systems,42(2), 1187-1202. http://doi.org/10.1016/j.dss.2005.10.004.

[57] Kim, H., \& Lennon, S. J. (2010). E-atmosphere, emotional, cognitive, and behavioral responses. Journal of Fashion Marketing and Management: An International Journal,14(3), 412-428. http://doi.org/10.1108/13612021011061861.

[58] Kim, H., \& Song, J. (2010). The quality of word-of-mouth in the online shopping mall. Journal of Research in Interactive Marketing, 4(4), 376390. http://doi.org/10.1108/17505931011092844.

[59] Kim, J., \& Lennon, S. J. (2013). Effects of reputation and website quality on online consumers' emotion, perceived risk and purchase intention: Based on the stimulusorganism-response model. Journal of Research in Interactive Marketing, 7(1), 3356.http://doi.org/10.1108/17505931311316734.

[60] Kim, Y.-E. (2016). Impact of gender differences in DNA on consumer buying behavior.Journal of Distribution Science, 14(2), 33-39. http://doi.org/10.15722/jds.14.2.201602.33

[61] Kotler, P. (Philip J. Keller, K. L., \& Keller, K. L. (2012). Marketing management. In Marketing Management (Vol. 37, pp. 40-47). Retrieved from http://biblioteca.porto.ipam.pt/cgi-bin/koha/opac-detail.pl?biblionumber=6373.

[62] Kotler, P. and Keller, K. (2009). Marketing managemen. 1st Ed. Upper Saddle River, N.J.:Pearson Prentice Hall.

[63] Kotler, P., \& Armstrong, G. (2008). Empresa y estrategias de marketing. In Marketing (pp.33-67). http://doi.org/10.1186/1745-6215-11-48

[64] Kotler, P., \& Keller, K. L. (2007). Marketing Management. Organization, XLIV, 816.Retrieved from http://usir.salford.ac.uk/4476/.

[65] Koufaris, M., Model, T. A., \& Behavior, O. C. (2002). Applying the Technology Acceptance Model and Flow Theory to Online Consumer Behavior. Information Systems, 13(2), 205-223. http://doi.org/10.1287/isre.13.2.205.83.

[66] Koufaris. (2002). Applying the Technology Acceptance Model and Flow Theory to Online Consumer Behavior. Information Systems Research, 13(2), 205-223.http://doi.org/10.1287/isre.13.2.205.83.

[67] Kusumah, R. (2015). Analyze the Effect of Trust, Price, Quality and Perceived Risk Toward Consumer urchase Behavior in Online Shops In stagram. JurnalBerkalaIlmiahEfisiensi, 15(15), 355-366.

[68] Kusumowidagdo, A. (2012). Pengaruhdesainatmosfertokoterhadapperilakubelanjastudiataspengaruh gender terhadapresponpengunjungtoko. International Research Journal of Business Studies, 3(1).

[69] Lee, Z. C., Yurchisin, J., \& Lin, C. Te. (2010). The impact of website attractiveness,consumer-website identification, and website trustworthiness on purchase intention. In Proceedings - 9th IEEE/ACIS International Conference on Computer and Information Science, ICIS 2010 (pp. 301-306). http://doi.org/10.1109/ICIS.2010.148.

[70] Li, X. (2007). Agent-based consumer learning in e-commerce. International Journal of Networking and Virtual Organisations, 4(1), 65.http://doi.org/10.1504/IJNVO.2007.012083.

[71] Liao, C., Palvia, P., \& Lin, H. N. (2010). Stage antecedents of consumer online buying behavior. Electronic Markets, 20(1), 53-65. http://doi.org/10.1007/s12525-010-0030-2.

[72] Limbu, Y. B., Huhmann, B. A., \& Xu, B. (2012). Are college students at greater risk of credit card abuse Age, gender, materialism and parental influence on consumer response to credit cards. Journal of Financial Services Marketing. http://doi.org/10.1057/fsm.2012.9.

[73] Lin, J., Yan, Y., Chen, S., \& Luo, X. (Robert). (2017). Understanding the Impact of Social Commerce Website Technical Features on Repurchase Intention: a Chinese Guanxi Perspective. Journal of Electronic Commerce Research, 18(3), 225-244.

[74] Lin, S. W., \& Lo, L. Y. S. (2016). Evoking online consumer impulse buying through virtual layout schemes. Behaviour and Information Technology, 35(1), 38-56.http://doi.org/10.1080/0144929X.2015.1056546.

[75] Liu, Y., Wan, H., \& Yang, X. (2010). Online Consumer Behavior. 2010 International Conference on Computer and Communication Technologies in Agriculture Engineering,270-273. http://doi.org/10.1109/CCTAE.2010.5544499.

[76] Lorenzo-Romero, C., Alarcón-del-Amo, M.-C., \& Gómez-Borja, M.-Á. (2016). Analyzing the User Behavior toward Electronic Commerce Stimuli. Frontiers in Behavioral Neuroscience, 10. http://doi.org/10.3389/fnbeh.2016.00224.

[77] Luna, D., Peracchio, L. A., \& De Juan, M. D. (2002). Cross-cultural and cognitive aspects of web site navigation. Journal of the Academy of Marketing Science. http://doi.org/10.1177/009207002236913.

[78] Martin, R. C., \& Dahlen, E. R. (2005). Cognitive emotion regulation in the prediction of depression, anxiety, stress, and anger. Personality and Individual Differences, 39(7), 1249-1260. http://doi.org/10.1016/j.paid.2005.06.004. 
[79] Meyer, C., \&Schwager, A. (2007). Understanding customer exprience. Harvard Business Review. http://doi.org/10.1108/00242539410067746.

[80] Milan, G. S., Bebber, S., Toni, D. De, \& Eberle, L. (2015). Information Quality, Distrust and Perceived Risk as Antecedents of Purchase Intention in the Online Purchase Context. Journal of Management Information System \& E-Commerce.http://doi.org/10.15640/jmise.v2n2a2.

[81] Nurgayatri, A. R. (2016). PengaruhPromosi Online Pada Media SosialTerhadap Keputusan PembelianKonsumen Brand Elmeira. FakultasEkonomi Dan Bisnis, Universitas Telkom, 3(3), 2679-2687.

[82] Park, C.-H., \& Kim, Y.-G. (2003). Identifying key factors affecting consumer purchase behavior in an online shopping context. International Journal of Retail \& Distribution Management, 31(1), 16-29. http://doi.org/10.1108/09590550310457818.

[83] Pluzinski, C., \& Qualls, W. J. (1975). Consumer Response to Marketing Stimuli. Advances in Consumer Research, 231-234.

[84] Pomirleanu, N., Schibrowsky, J. a., Peltier, J., \&Nill, A. (2013). A review of internet marketing research over the past 20 years and future research direction. Journal of Research in Interactive Marketing, 7(3), 166-181. http://doi.org/10.1108/JRIM-01-2013-0006.

[85] Prajitno, S. B. (2008). MetodologiPenelitianKuantitatif. Komunikasipenelitiankuantitatif Program StudiJurnalistik\&Humas, 1-29. http://doi.org/10.1017/CBO9781107415324.004.

[86] Priambodo, S., \& Prabawani, B. (2016). pengaruh persepsi manfaat, persepsi kemudahan penggunaan, dan persepsi risiko terhadap minat menggunakan layanan uang elektronik (Studi Kasus pada Masyarakat di Kota Semarang ). JurnallmuAdministrasiBisnis, 5(2),1-9.

[87] Rohm, A. J., \& Swaminathan, V. (2004). A typology of online shoppers based on shopping motivations. Journal of Business Research, 57(7), 748757. http://doi.org/10.1016/S0148-2963(02)00351-X.

[88] Rosen, D. E., \&Purinton, E. (2004). Website design. Journal of Business Research, 57(7), 787-794. http://doi.org/10.1016/S0148-2963(02)00353$\underline{3}$.

[89] Rosenkrans, G. (2010). Maximizing user interactivity through banner ad design. Journal of Promotion Management, 16(3), 265-287. http://doi.org/10.1080/10496490903582586.

[90] Salehi, M. (2011). Consumer buying behavior towards online shopping stores in Malaysia. International Journal of Academic Research in Accounting, Finance and Management Sciences, 1(2), 10. http://doi.org/10.6007/ijarafms.v1i2.8.

[91] Santoso, B. (2009). RisetPerilakuKonsumenStudiMengenaiPerlakuKonsumenTerhadap Online Shopping.JurnalPerilakuKonsumen, 1-10.

[92] Schultz, D. E., \& Peltier, J. J. (2013). Social media's slippery slope: challenges,opportunities and future research directions. Journal of Research in Interactive Marketing,7(2), 86-99. http://doi.org/10.1108/JRIM-12-2012-0054.

[93] Setiadi, N. J. (2008). Perilakukonsumen: konsep dan implikasiuntukstrategi dan penelitianpemasaran. 1. KONSUMEN, PERILAKU<BR>2. PEMASARAN,PerilakuKonsumen: Konsep Dan ImplikasiUntukStrategi Dan PenelitianPemasaran / Nugroho J.Setiadi, 2008(2008), 1-99. http://doi.org/10.1016/j.jns.2006.05.033.

[94] Steils, N., Crié, D., \&Decrop, A. (2018). Online consumer learning as a tool for improving product appropriation. Journal of Retailing and Consumer Services.http://doi.org/10.1016/j.jretconser.2018.04.007

[95] Sundar, S. S., \&Kalyanaraman, S. (2004). Arousal, memory, and impression-formation effects of animation speed in web advertising. Journal of Advertising, 33(1), 7-17. http://doi.org/10.1080/00913367.2004.10639152.

[96] Tiago, M. T. P. M. B., \& Ver??ssimo, J. M. C. (2014). Digital marketing and social media: Why bother? Business Horizons, 57(6), 703708.http://doi.org/10.1016/j.bushor.2014.07.002

[97] Tolman, E. C. (1938). Physiology, psychology, and sociology. Psychological Review,45(3), 228-241. http://doi.org/10.1037/h0060722.

[98] Vachhani, N. V, \&Bhayani, S. (2012). Predictors of Online Consumer Behavior. Journal of Commerce and Accounting Research, 1(3), 45-50. Retrieved from https://libproxy.wlu.ca/login?url=http://search.proquest.com/docview/1490568586?account id=15090\%0Ahttp://sfx.scholarsportal.info/laurier?url_ver=Z39.88-004\&rft_val_fmt=info:ofi/

[99] Yoon, C. (2010). Antecedents of customer satisfaction with online banking in China: The effects of experience. Computers in Human Behavior, 26(6), 1296-1304. http://doi.org/10.1016/j.chb.2010.04.001.

[100] Zhonghua, W. (2012). Analysis of Internet Consumer Behavior and Enterprise Strategies in China. In proceedings of the sixth international symposium - the development of small and medium-sized enterprises (pp. 65-69). http://doi.org/10.5503/J.CL.2014.14.008. 